\title{
Pengembangan bahan ajar interaktif multi representasi pada materi geometri kelas VII SMPLB tunarungu
}

\author{
I Kadek Yasa Sumalasia ${ }^{1}$, I Made Suarsana 1 * (iD), I Wayan Puja Astawa 1 \\ 1 Jurusan Matematika, Universitas Pendidikan Ganesha, Singaraja, Indonesia \\ * Corresponding Author. E-mail: suarsana1983@gmail.com
}

\begin{tabular}{|c|c|}
\hline ARTICLE INFO & ABSTRACT \\
\hline $\begin{array}{l}\text { Keywords: } \\
\text { Pengembangan bahan ajar } \\
\text { interaktif, } \\
\text { Multi representasi, } \\
\text { Siswa tunarungu, } \\
\text { Development of Interactive } \\
\text { learning material, } \\
\text { Multi representation, } \\
\text { Hearing-impaired student. }\end{array}$ & $\begin{array}{l}\text { Penelitian ini merupakan penelitian pengembangan yang ditujukan untuk menghasilkan bahan } \\
\text { ajar interaktif multi representasi pada materi geometri untuk siswa kelas VII Sekolah Menengah } \\
\text { Pertama Luar Biasa (SMPLB) Tunarungu yang layak dalam hal kevalidan, kepraktisan, dan ke- } \\
\text { efektifannya. Untuk menghasilkan bahan ajar tersebut, model pengembangan ADDIE (Analysis, } \\
\text { Design, Development, Implementation, Evaluation) digunakan dalam penelitian ini. Subjek uji } \\
\text { coba penelitian adalah } 10 \text { siswa kelas VII SMPLB di salah satu SLB Negeri di Kabupaten Buleleng, } \\
\text { Bali. Instrumen yang digunakan dalam penelitian ini terdiri atas: (1) lembar validasi materi, keba- } \\
\text { hasaan, penyajian, dan kegrafikan untuk menilai kevalidan; (2) angket respons guru dan siswa } \\
\text { untuk menilai kepraktisan; dan (3) tes hasil belajar untuk menilai keefektifan bahan ajar yang } \\
\text { dikembangkan. Penelitian ini menghasilkan bahan ajar interaktif multi representasi yang valid, } \\
\text { praktis, dan efektif. Hasil validasi menunjukkan bahwa bahan ajar yang dikembangkan berada } \\
\text { pada kriteria valid. Hasil analisis angket respons guru dan siswa berturut-turut menunjukkan } \\
\text { bahwa kepraktisan bahan ajar yang dikembangkan berada pada kriteria sangat tinggi dan tinggi. } \\
\text { Bahan ajar yang dikembangkan juga memenuhi kriteria keefektifan, di mana sebanyak } 90 \% \\
\text { subjek uji coba memperoleh skor tidak kurang dari } 76 \text { pada tes hasil belajar. Dengan demikian, } \\
\text { dapat disimpulkan bahwa bahan ajar yang dikembangkan layak digunakan untuk mendukung } \\
\text { dan memfasilitasi siswa tunarungu dalam belajar geometri. }\end{array}$ \\
\hline
\end{tabular}

This study was development research which was aimed to produce an interactive learning material with multi representation approach in the topic of geometry for the 7th-grade hearingimpaired students of Special Junior High School (Sekolah Menengah Pertama Luar Biasa or SMPLB), which was feasible in terms of its validity, practicality, and effectiveness. To produce interactive learning material, the development model of ADDIE (Analysis, Design, Development, Implementation, and Evaluation) was used. The trial subjects were ten 7th graders of SMPLB in one of the special public schools in Buleleng Regency, Bali, Indonesia. The instruments which were used comprised of: (1) validation sheet of content, language, layout, and graphical to assess the validity; (2) teacher and students response questionnaires to assess the practicality; and (3) test of learning achievement to assess the effectiveness of the developed learning material. This study yielded an interactive learning material that was valid, practical, and effective. The results of validation showed that the developed learning material at valid criteria. The results of the teacher and student response questionnaire consecutively showed that the practicality of developed learning material at the very high and high practical criteria. The developed learning material also meets the effectiveness criteria, in which as many as $90 \%$ of the trial subjects got score not less than 76 on the test of learning achievement. Consequently, it can be concluded that the developed learning material was feasible to use to support and facilitate the hearing-impaired students in learning geometry.

This is an open access article under the CC-BY-SA license

\section{How to Cite:}

Sumalasia, I. K. Y., Suarsana, I. M., \& Astawa, I. W. P. (2020). Pengembangan bahan ajar interaktif multi representasi pada materi geometri kelas VII SMPLB tunarungu. Pythagoras: Jumal Pendidikan Matematika, 15(1), 36-47. https://doi.org/10.21831/pg.v15i1.25851 


\section{PENDAHULUAN}

Setiap warga negara berhak mendapatkan pendidikan, termasuk anak-anak yang berkebutuhan khusus (ABK). Hal ini ditegaskan dalam peraturan mengenai pendidikan untuk ABK, yaitu Undang-Undang Nomor 20 Tahun 2003 tentang Sistem Pendidikan Nasional (Presiden Republik Indonesia, 2003), bahwa "warga negara yang memiliki kelainan fisik, emosional, mental, intelektual, dan/atau sosial berhak memperoleh pendidikan khusus" (p.4). Pemberian hak ini kemudian diwujudkan oleh pemerintah Indonesia melalui penyediaan fasilitas yang berupa Sekolah Luar Biasa (SLB) yang mana sekolah ini sudah tersedia di tiap kabupaten/kota di Indonesia. Pada umumnya, terdapat lima jenis SLB, mulai dari SLB-A hingga SLB-E, yang dibedakan berdasarkan jenis kebutuhan khusus. Adapun khusus untuk anak-anak tunarungu atau anak yang mengalami gangguan dalam hal pendengaran akan difasilitasi dalam belajar atau memperoleh pendidikan di SLB dengan jenis SLB-B. Berdasarkan Permendiknas Nomor 33 Tahun 2008 tentang Standar Sarana dan Prasarana untuk SLB (Kemendiknas, 2008), pada idealnya, setidaknya ada satu Sekolah Dasar Luar Biasa (SDLB) dan satu Sekolah Menengah Pertama Luar Biasa (SMPLB) di setiap kabupaten/kota di Indonesia. Sehubungan dengan hal ini, di Kabupaten Buleleng, Bali, saat ini sudah terdapat dua SLB yang berstatus negeri.

Pada SLB jenis SLB-B, anak-anak tunarungu diberikan pendidikan khusus di mana muatan pendidikan khusus tersebut terdiri atas $70 \%$ aspek keterampilan dan $30 \%$ aspek akademik (Liando \& Dapa, 2007). Pada aspek akademik, siswa di SLB tersebut diberikan mata pelajaran umum dengan tingkat kesulitan yang tentunya lebih rendah bila dibandingkan dengan apa yang dipelajari oleh siswa di sekolah biasa. Muatan kurikulum yang diperuntukkan bagi siswa tunarungu pada jenjang pendidikan Sekolah Dasar Luar Biasa (SDLB) hingga Sekolah Menengah Atas Luar Biasa (SMALB) dirancang setara dengan muatan kurikulum yang berlaku untuk pendidikan reguler (biasa) pada jenjang Pendidikan Anak Usia Dini (PAUD) hingga kelas VI SD ditambah dengan program kebutuhan khusus dan pilihan kemandirian (Kemendikbud, 2014). Salah satu mata pelajaran umum yang dibelajarkan kepada siswa SLB$B$ adalah matematika. Matematika merupakan salah satu mata pelajaran yang dianggap sulit bagi atau oleh siswa pada umumnya (Gafoor \& Kurukkan, 2015; Gazali, 2016; Novitasari, 2016; Siregar, 2017; Yeni, 2015). Hal ini dapat dikarenakan oleh banyak kemungkinan yang salah satu kemungkinan tersebut adalah banyaknya bahasan-bahasan pada pelajaran matematika yang bersifat abstrak (Novitasari, 2016, p.8; Yeni, 2015, p.7). Bahkan Gafoor dan Kurukkan (2015, p.233) menyatakan bahwa dalam belajar matematika, siswa memerlukan proses kognitif yang lebih tinggi karena pada hakikatnya konten dan proses dalam matematika itu bersifat abstrak dan saling berkaitan. Lebih lanjut, melalui penelitiannya, Gafoor dan Kurukkan $(2015$, p.238) mengungkapkan bahwa alasan besar yang melatarbelakangi adanya anggapan dari siswa bahwa matematika merupakan mata pelajaran yang sulit adalah kurangnya pengetahuan awal yang dimiliki oleh siswa untuk mempelajari materi yang lebih kompleks. Tentu hal itu semua akan menjadi tantangan yang lebih besar bagi siswa berkebutuhan khusus, termasuk bagi siswa penyandang tunarungu. Mereka akan kesulitan dalam memahami konteks matematika yang bersifat abstrak karena terkendala oleh masalah komunikasi. Hernawati (2007) menyebutkan bahwa masalah komunikasi, lisan atau verbal, merupakan hambatan yang dialami oleh siswa tunarungu, sehingga ini dapat menghambat mereka dalam proses pembelajaran. Bahkan hambatan tersebut dapat berpengaruh terhadap keterampilan sosial, akademik, dan bahasa mereka (Hidayat et al., 2017).

Dengan pesatnya perkembangan teknologi saat ini yang sudah memasuki era Revolusi Industri 4.0, pendidik dan siswa dapat secara mudah mengakses ataupun mencari bahan ajar dan buku referensi. Kemudahan yang diakibatkan oleh perkembangan teknologi tersebut hendaknya dapat dipadukan dengan pengetahuan yang dimiliki oleh tenaga pendidik, yang dalam hal ini adalah guru, dalam menyediakan atau mengombinasikan bahan ajar yang satu dengan bahan ajar lainnya. Hal tersebut untuk menunjang pembelajaran dan membantu siswa dalam meminimalisir atau mengatasi dampak yang mungkin ditimbulkan oleh adanya hambatan komunikasi. Ini menjadi penting mengingat komunikasi sangat diperlukan dalam mendukung keberhasilan proses pembelajaran, baik komunikasi secara verbal maupun non-verbal (Rawat, 2016), bahkan proses pembelajaran tidak akan dapat berlangsung tanpa adanya komunikasi (Duta et al., 2015). Selain itu, guru sebagai pendidikjuga diharapkan untuk lebih kreatif dalam memilih metode, teknik, atau strategi pembelajaran yang hendak diterapkan dalam memfasilitasi siswanya belajar, terlebih ketika memfasilitasi siswa tunarungu dalam belajar. Menurut Hidayati (2012), dalam pembelajaran sifat-sifat bangun datar pada siswa tunarungu di SLB-B, metode dan teknik yang diterapkan dalam pembelajaran tersebut tidak jauh berbeda dengan apa yang diterapkan di sekolah biasa pada umumnya. Akan tetapi, dari segi taktik pembelajaran, apa yang diterapkan di SLB-B dan di sekolah biasa tersebut sangat berbeda. 
Salah satu strategi yang dapat digunakan untuk memfasilitasi siswa tunarungu belajar yaitu dengan menggunakan bahan ajar yang tepat dan sesuai dengan keadaan dan kemampuan siswa tunarungu itu sendiri, seperti bahan ajar yang berisikan audio visual untuk menjelaskan materi yang dibelajarkan, sehingga siswa dapat memahami materi dengan lebih maksimal.

Beberapa bahan ajar matematika khusus untuk siswa SMPLB Tunarungu telah dihasilkan oleh penelitian terdahulu. Astuti dan Trisnawati (2013), melalui penelitian dan pengembangan yang telah dilakukannya, berhasil mengembangkan bahan ajar matematika kontekstual dengan bahasa yang sederhana dengan dilengkapi visualisasi konsep. Bahan ajar tersebut efektif dalam memfasilitasi siswa kelas XI SMPLB Tunarungu dalam mengembangkan pemahamannya terhadap konsep matematika. Selanjutnya, Sholihah et al. (2015), melalui penelitian pengembangan dengan model pengembangan $4 \mathrm{D}$, menghasilkan bahan ajar berupa buku siswa untuk siswa kelas VII SMPLB Tunarungu. Bahan ajar ini didesain agar dapat mengembangkan hasil belajar siswa dan menumbuhkan minat siswa dalam memahami materi hubungan dua garis, besar sudut, dan jenis sudut melalui penyajian ilustrasi gambar. Suarsana et al. (2018), melalui penelitian pengembangan dengan menggunakan model pengembangan 4D, menghasilkan media pembelajaran statistika interaktif yang valid untuk siswa kelas VII SMPLB Tunarungu. Salah satu karakteristik dari media yang dihasilkan tersebut adalah tersedianya visualisasi yang menarik yang disesuaikan dengan karakteristik siswa tunarungu. Suarsana et al. (2019) menghasilkan media pembelajaran matematika interaktif pada materi peluang, di mana media ini selanjutnya diterapkan dalam pembelajaran, melalui eksperimen se$\mathrm{mu}$, untuk mendeskripsikan pengaruh dari media tersebut terhadap pemahaman konseptual siswa kelas VII SLB. Media ini memiliki pengaruh yang baik terhadap pemahaman konseptual siswa pada materi peluang, di mana pengaruh ini dimungkinkan karena karakteristik dari media tersebut yang memfasilitasi kebutuhan siswa dalam hal representasi visual. Terakhir, melalui penelitian pengembangan dengan menggunakan model pengembangan ADDIE, Suarcita et al. (2020) menghasilkan bahan ajar interaktif digital multi representasi pada materi bilangan bulat yang dikhususkan untuk siswa kelas VII SMPLB Tunarungu. Bahan ajar ini setelah diujicobakan ternyata mampu mendukung sebagian besar siswa tunarungu dalam mencapai ketuntasan minimum hasil belajar. Berdasarkan penelitian-penelitian yang telah dilakukan tersebut, salah satu cara yang dapat digunakan untuk memfasilitasi kebutuhan siswa tunarungu dalam meningkatkan pemahamannya terhadap materi matematika yang mereka pelajari adalah melalui visualisasi materi.

Visualisasi materi pembelajaran merupakan salah satu metode yang penting untuk memfasilitasi siswa tunarungu dalam proses pembelajaran (Astuti \& Trisnawati, 2013; Krasavina et al., 2019). Ketika ketersediaan visualisasi materi tersebut terbatas, proses belajar siswa mungkin akan berlangsung secara kurang maksimal, termasuk pemahaman siswa terhadap materi pembelajaran juga kurang maksimal dan bahkan bisa jadi mengalami kesulitan dalam memahami materi tersebut. Salah satu upaya yang dapat digunakan untuk mengatasi kesulitan yang dialami oleh siswa tunarungu dalam memahami materi yang diajarkan oleh guru adalah dengan menggunakan pendekatan multi representasi dalam penyampaian materi tersebut. Waldrip et al. (2006) mendeskripsikan multi representasi sebagai praktik merepresentasikan kembali suatu konsep yang sama ke dalam bentuk yang berbeda, yang mencakup ragam bentuk representasi deskriptif (verbal, grafik, dan tabel), eksperimental, matematis, figuratif (piktorial, analogi, dan metafora), kinestetik, visual atau mode aksional operasional. Dengan demikian, multi representasi dapat dipahami sebagai suatu pendekatan untuk menjelaskan suatu konsep atau materi dari suatu masalah yang digunakan untuk menemukan solusi atas masalah tersebut dengan cara atau format yang berbeda-beda berdasarkan interpretasi pikiran agar menjadi lebih bermakna. Pendekatan multi representasi ini sejalan dengan pendekatan yang biasa digunakan dalam pembelajaran materi geometri seperti pendekatan van Hiele, di mana salah satu hal yang menjadi penekanan dalam pendekatan tersebut adalah visualisasi materi pembelajaran, yang dalam hal ini adalah materi geometri. Dengan menggunakan pendekatan tersebut diharapkan akan dapat memudahkan siswa tunarungu dalam memahami materi yang diajarkan, khususnya dalam materi geometri, sesuai dengan kurikulum yang digunakan di sekolah.

Berdasarkan hasil observasi dan wawancara terhadap guru matematika kelas VII SMPLB Tunarungu di salah satu SLB yang berstatus negeri di Kabupaten Buleleng diperoleh informasi bahwa permasalahan-permasalahan siswa dalam pembelajaran matematika pada sekolah umum juga dialami oleh siswa pada sekolah luar biasa. Bahkan permasalahan pembelajaran matematika pada siswa tunarungu lebih kompleks dikarenakan adanya keterbatasan fungsi indra pendengaran dan kurangnya kosakata dalam berkomunikasi. Pembelajaran matematika masih banyak terkendala dalam hal penyampaian materi, khususnya pada materi geometri. Pada pembelajaran materi geometri tersebut, sebagian besar siswa tunarungu mengalami kesulitan untuk menghitung keliling dan luas 
bangun datar, khususnya bangun segitiga dan segi empat. Selain itu, mereka juga mengalami kesulitan untuk memvisualisasikan bangun datar tersebut jika mereka hanya mencermati gambar diam seperti pada buku ajar, slide, atau gambar yang disajikan oleh guru di papan tulis karena mereka tidak dapat berinteraksi atau terlibat langsung dengan gambar tersebut. Hal semacam ini, lebih lanjut, akan menghambat proses pembelajaran. Selain itu, hal ini juga bertolak belakang dengan pembelajaran yang sesuai dengan prinsip pembelajaran sesuai Kurikulum 2013, yaitu pembelajaran seharusnya berpusat pada siswa, di mana siswa sendirilah yang harus aktif mencari atau mengeksplorasi pengetahuan yang dibutuhkan oleh mereka. Berkaitan dengan keadaan tersebut, bahan ajar yang tersedia juga masih terbatas pada menampilkan gambar dan cara menghitung pun dikomunikasikan secara verbal. Bagi siswa tunarungu, tentu ini akan menjadi kendala mengingat karakteristik dari matematika yang mungkin sulit untuk disampaikan kepada siswa secara lisan karena minimnya kosakata yang dimiliki oleh mereka. Oleh karena itu, tidak jarang terjadi ketidaksesuaian antara apa yang disampaikan oleh guru dan apa yang dipahami atau ditangkap oleh siswa yang berakibat pada rendahnya hasil belajar matematika siswa tunarungu.

Salah satu upaya untuk mengatasi ketidaksesuaian dalam hal komunikasi antara guru dan siswa serta keterbatasan siswa dalam menggunakan buku ajar yang didapat di sekolah, yaitu dengan menggunakan bahan ajar interaktif. Bahan ajar ini dibuat dengan menggunakan aplikasi exe learning yang memberikan luaran berupa bahan ajar interaktif sehingga dalam proses pembelajaran dan penyampaian materi melibatkan tampilan audiovisual seperti audio, video, grafis, animasi, dan teks. Dengan begitu, siswa akan merasa tertarik untuk membuka dan mengeksplorasi isi dari bahan ajar interaktif tersebut. Bahan ajar interaktif ini dapat dikontrol secara langsung oleh penggunanya, yang dalam hal ini adalah siswa. Dengan penggunaan exe learning untuk membuat bahan ajar interaktif, yang dalam penyam paian isi atau materinya menggunakan pendekatan multi representasi, diharapkan dapat membantu siswa tunarungu dalam mengatasi kesulitannya. Berdasarkan potensi dari bahan ajar interaktif ini, potensi dari penggunaan pendekatan multi representasi, permasalahan yang ada dalam pembelajaran geometri pada siswa tunarungu, dan ketersediaan bahan ajar matematika untuk siswa tunarungu yang dihasilkan oleh penelitian pengembangan terdahulu, maka penelitian ini bertujuan untuk menghasilkan bahan ajar interaktif multi representasi pada materi geometri kelas VII SMPLB Tunarungu.

\section{METODE}

Penelitian yang dilakukan ini merupakan penelitian pengembangan (Research and Development, R \& D) yang bertujuan untuk menghasilkan produk yang layak untuk digunakan ditinjau dari aspek kevalidan, kepraktisan, dan keefektifan. Produk yang dihasilkan berupa bahan ajar interaktif multi representasi pada materi geometri pada mata pelajaran matematika untuk siswa kelas VII SMPLB Tunarungu. Penelitian ini dilakukan dengan menggunakan model pengembangan ADDIE. Model pengembangan ini terdiri atas lima tahap pengembangan, yaitu: analisis (analysis), perancangan (design), pengembangan (development), implementasi (implementation), dan evaluasi (evaluation). Secara umum, tahapan pengembangan dan luaran yang diharapkan disajikan dalam Tabel 1.

Subjek dalam penelitian ini adalah 10 siswa kelas VII SMPLB Tunarungu di SLB Negeri 1 Buleleng, Bali. Adapun instrumen yang digunakan untuk mengetahui kelayakan dari bahan ajar yang dikembangkan terdiri atas lembar validasi materi, lembar validasi kebahasaan, lembar validasi penyajian, lembar validasi kegrafikan (Akpinar, 2008), angket respons guru, angket respons siswa, dan tes hasil belajar. Masing-masing lembar validasi memiliki tiga kategori penilaian, yaitu baik mendapat skor 3, cukup mendapat skor 2, dan kurang mendapat skor 1 . Adapun penilaian pada angket respons siswa dan guru menggunakan lima kategori penilaian, yaitu skor 5 untuk sangat setuju, skor 4 untuk setuju, skor 3 untuk ragu-ragu, skor 2 untuk kurang setuju, dan skor 1 untuk tidak setuju yang berlaku pada setiap pernyataan positif dan berlaku sebaliknya untuk setiap pernyataan negatif. Tes hasil belajar yang digunakan berupa tes objektif yang berbentuk pilihan ganda dengan empat pilihan jawaban. Dalam penelitian ini digunakan dua jenis teknik analisis data, yaitu teknik data analisis kualitatif dan deskriptif kuantitatif. Teknik analisis data kualitatif digunakan untuk menganalisis data hasil review dari para ahli, angket respons siswa dan guru dalam menggunakan bahan ajar materigeometri, serta catatan harian yang berupa catatan-catatan penting terkait proses belajar siswa maupun tahap pengembangan produk. Adapun teknik analisis data deskriptif kuantitatif digunakan untuk mengolah dan menganalisis data hasil validasi oleh ahli, angket respons siswa dan guru, dan hasil tes prestasi belajar. Hasil dari analisis data tersebut kemudian digunakan untukmengetahui kevalidan, kepraktisan, dan keefektifan dari produk berupa bahan ajar interaktif yang dikembangkan. 
Tabel 1. Tahapan pengembangan bahan ajar interaktif dan luaran yang diharapkan

\begin{tabular}{|c|c|c|}
\hline Tahap pengembangan & Kegiatan & Luaran yang diharapkan \\
\hline \multirow[t]{3}{*}{$\begin{array}{l}\text { Analisis } \\
\text { (analysis) }\end{array}$} & Analisis kebutuhan & $\begin{array}{l}\text { Teridentifikasi permasalahan yang ada dalam } \\
\text { proses pembelajaran dan kondisi bahan ajar } \\
\text { matematika kelas VII di SMPLB Tunarungu }\end{array}$ \\
\hline & Analisis kurikulum & $\begin{array}{l}\text { Diketahui batasan dari materi geometri pada } \\
\text { Kurikulum } 2013 \text { untuk siswa kelas VII SMPLB } \\
\text { Tunarungu }\end{array}$ \\
\hline & Analisis karakteristik siswa & $\begin{array}{l}\text { Diketahui karakteristik siswa tuna rungu sehingga } \\
\text { media yang dibuat akan sesuai dengan kebutuhan } \\
\text { siswa tunarungu }\end{array}$ \\
\hline $\begin{array}{l}\text { Perancangan } \\
\text { (design) }\end{array}$ & $\begin{array}{l}\text { Menyusun bahan ajar inte- } \\
\text { raktif beserta instrumen } \\
\text { evaluasinya }\end{array}$ & $\begin{array}{l}\text { Tersusunnya bahan ajar interaktif dalam wujud } \\
\text { prototipe I yang siap divalidasi oleh validator }\end{array}$ \\
\hline \multirow[t]{2}{*}{$\begin{array}{l}\text { Pengembangan } \\
\text { (development) }\end{array}$} & $\begin{array}{l}\text { Penilaian kevalidan dari } \\
\text { bahan ajar interaktif, yaitu } \\
\text { prototipe I, oleh validator }\end{array}$ & $\begin{array}{l}\text { Diperoleh komentar dan saran dari pada ahli } \\
\text { (validator) terkait dengan bahan ajar interaktif, yaitu } \\
\text { prototipe l, yang dihasilkan }\end{array}$ \\
\hline & $\begin{array}{l}\text { Melakukan revisi/perbaikan } \\
\text { terhadap bahan ajar interaktif } \\
\text { yang dikembangkan }\end{array}$ & $\begin{array}{l}\text { Diperoleh bahan ajar interaktif yang sudah direvisi } \\
\text { sesuai dengan masukan para ahli (validator). Bahan } \\
\text { ajar hasil revisi ini selanjutnya disebut sebagai } \\
\text { prototipe II }\end{array}$ \\
\hline $\begin{array}{l}\text { Implementasi } \\
\text { (implementation) }\end{array}$ & $\begin{array}{l}\text { Melakukan uji coba terbatas } \\
\text { di SLB Negeri } 1 \text { Buleleng }\end{array}$ & $\begin{array}{l}\text { Diperoleh data tentang kepraktisan dan keefektifan } \\
\text { dari bahan ajar interaktif (prototipe II) yang } \\
\text { dikembangkan }\end{array}$ \\
\hline $\begin{array}{l}\text { Evaluasi } \\
\text { (evaluation) }\end{array}$ & $\begin{array}{l}\text { Melakukan revisi berdasarkan } \\
\text { hasil uji coba terbatas yang } \\
\text { telah dilakukan di sekolah }\end{array}$ & $\begin{array}{l}\text { Dihasilkannya bahan ajar interaktif yang layak } \\
\text { digunakan dalam pembelajaran (prototipe akhir) }\end{array}$ \\
\hline
\end{tabular}

Kevalidan produk yang dikembangkan dihitung dengan menggunakan rumus $\bar{X}=\left(\sum X\right) / n$, di mana $\bar{X}$ menyatakan rata-rata skor dari validator, $\sum X$ menyatakan jumlah skor validitas yang diperoleh dari validator, dan $n$ menyatakan banyaknya butir pernyataan. Hasil perhitungan ini kemudian diinterpretasikan ke dalam kriteria validitas bahan ajar interaktif yang telah ditetapkan (lihat Tabel 2). Bahan ajar interaktif yang dikembangkan dikatakan memenuhi kriteria kevalidan apabila rata-rata skor validitas yang diperoleh minimum mencapai skor 1,68 atau minimal berada pada kriteria cukup valid.

Tabel 2. Kriteria kevalidan bahan ajar interaktif yang dikembangkan

\begin{tabular}{ll}
\hline Interval rata-rata skor validator & Kriteria \\
\hline $2,36 \leq \bar{X} \leq 3,00$ & Valid \\
$1,68 \leq \bar{X}<2,36$ & Cukup valid \\
$1,00 \leq \bar{X}<1,68$ & Tidak valid \\
\hline & Sumber: Muhidin dan Abdurahman (2007)
\end{tabular}

Kepraktisan produk yang dikembangkan juga dihitung berdasarkan rumus $\bar{X}=\left(\sum X\right) / n$, dengan $\bar{X}$ menyatakan rata-rata skor dari penilaian guru dan siswa, $\sum X$ menyatakan jumlah skor dari penilaian guru dan siswa, dan $n$ menyatakan banyaknya butir pernyataan pada angket respons guru dan siswa. Hasil perhitungan yang diperoleh dengan menggunakan rumus tersebut selanjutnya dikonversikan ke dalam kriteria kepraktisan yang telah ditetapkan (lihat Tabel 3). Produk yang dikembangkan dikatakan layak ditinjau dari aspek kepraktisan jika rata-rata skor dari penilaian guru dan siswa minimum mencapai 2,60 atau berada pada kriteria kepraktisan sedang. 
PYTHAGORAS: Jurnal Pendidikan Matematika, 15 (1), 2020 - 41

I Kadek Yasa Sumalasia, I Made Suarsana, I Wayan Puja Astawa

Tabel 3. Kriteria kepraktisan bahan ajar interaktif yang dikembangkan

\begin{tabular}{lll}
\hline Interval rata-rata skor kepraktisan & Kriteria & Keterangan \\
\hline $4,20 \leq \bar{X} \leq 5,00$ & Sangat tinggi & Tidak perlu direvisi \\
$3,40 \leq \bar{X}<4,20$ & Tinggi & Tidak perlu direvisi \\
$2,60 \leq \bar{X}<3,40$ & Sedang & Tidak perlu direvisi \\
$1,80 \leq \bar{X}<2,60$ & Rendah & Direvisi \\
$1,00 \leq \bar{X}<1,80$ & Sangat rendah & Direvisi \\
\hline \multicolumn{2}{c}{ Sumber: Muhidin dan Abdurahman (2007) }
\end{tabular}

Terakhir, keefektifan produk berupa bahan ajar interaktif yang dikembangkan dalam penelitian ini dapat dilihat berdasarkan rata-rata hasil tes belajar siswa. Bahan ajar interaktif tersebut dikatakan efektif apabila setelah mengikuti pembelajaran dengan menggunakan bahan ajar interaktif pada materi geometri, minimum $85 \%$ dari seluruh subjek uji coba memenuhi ketuntasan belajar klasikal. Subjek uji coba dikatakan tuntas belajar ketika subjek uji coba tersebut memperoleh skor tes belajar minimum 76.

\section{HASIL PENELITIAN}

Setelah melalui tahap pengembangan, dihasilkan suatu bahan ajar interaktif multi representasi pada materi geometri kelas VII SMPLB Tunarungu yang telah dievaluasi. Pada pengembangan bahan ajar interaktif ini, dibuatlah rancang bangun (story board) yang digunakan sebagai pedoman dalam proses pembuatan bahan ajar interaktif menjadi sebuah program yang utuh. Rancang bangun dalam penelitian ini disusun secara sederhana, jelas, dan memuat beberapa hal, antara lain: (1) kompetensi dasar dan indikator pembelajaran yang ingin dicapai dalam pembelajaran menggunakan bahan ajar interaktifyang dikembangkan; (2) deskripsi kegiatan pada setiap halaman; (3) komponen-komponen yang termuat dalam setiap halaman; dan (4) desain tampilan setiap halaman. Deskripsi, komponen dan desain tampilan dalam rancang bangun dicantumkan secara sederhana, jelas, dan konsisten untuk memudahkan pengimplementasian rancang bangun menjadi program bahan ajar yang interaktif. Rancangan awal dari bahan ajar interaktif multi representasi pada materi geometri kelas VII SMPLB Tunarungu dapat dilihat pada Tabel 4 .

Tabel 4. Rancang bangun (story board) bahan ajar interaktif multi representasi

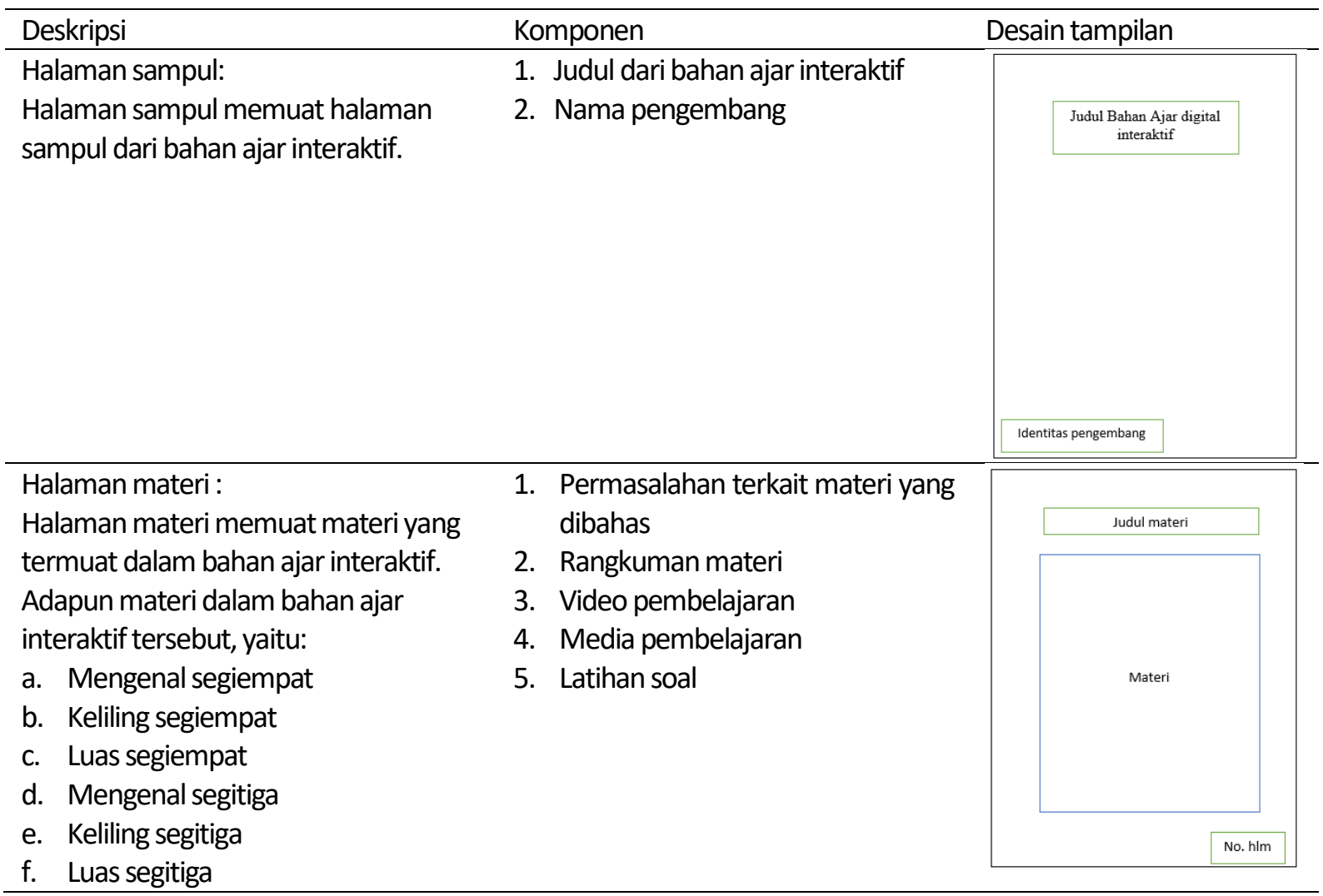


Setelah tersusun rancang bangun bahan ajar interaktif, rancang bangun tersebut diimplementasikan menjadi prototipe I dengan menggunakan aplikasi komputer. Pembuatan bahan ajar interaktif dalam penelitian ini menggunakan aplikasi Exe Learning, GeoGebra, dan VideoPad Video Editor. Hasil pengembangan bahan ajar tersebut berupa bahan ajar interaktif multi representasi materi geometri kelas VII SMPLB Tunarungu dengan format file dalam bentuk single site dan website untuk penggunaan pada laptop atau komputer dengan sistem operasi minimal Windows 7 atau MacOS X, dan dalam format EPUB3 untuk penggunaan pada smartphone dengan sistem operasi minimal Android 4.0 atau iOS 7.0. Untuk tampilan setiap halaman bahan ajar interaktif pada masing-masing format file secara umum sama. Perbedaannya hanya terletak pada cara navigasinya. Pada bahan ajar interaktif format single site, navigasi yang digunakan adalah dengan cara menggulung ke atas maupun ke bawah untuk mengubah halaman dalam bahan ajar interaktif. Bahan ajar interaktif pada format website menggunakan navigasi next untuk menuju ke halaman selanjutnya, previous untuk menuju ke halaman sebelumnya, dan menu untuk melihat dan memilih halaman melalui daftar menu. Pada bahan ajar interaktif format EPUB3 yang dijalankan pada smartphone menggunakan aplikasi gitden reader untuk navigasinya dilakukan dengan cara menggeser ke samping pada layar smartphone yang digunakan. Untuk membantu pengguna dalam memahami cara menggunakan bahan ajar interaktif materi geometri tersebut, peneliti juga membuat buku petunjuk umum tentang cara penggunaan bahan ajar interaktif yang dikembangkan. Dalam bahan ajar interaktif ini terdapat materi pelajaran, video pembelajaran, media eksplorasi, dan latihan soal terkait materi segiempat dan segitiga. Berikut akan diuraikan hal-hal yang termuat dalam bahan ajar interaktif dengan pendekatan multi representasi pada materi geometri kelas VII SMPLB Tunarungu.

Halaman awal yang muncul ketika bahan ajar baru dijalankan adalah halaman sampul (lihat Gambar 1). Halaman selanjutnya setelah halaman sampul adalah halaman materi dari bahan ajar interaktif (lihat Gambar 2). Pada halaman ini termuat materi pembelajaran terkait segitiga dan segi empat. Adapun materi yang dimaksud di sini meliputi: permasalahan dalam kehidupan sehari-hari yang terkait dengan masing-masing subbab materi, masalah dan penyelesaian masalah terkait dengan materi pembelajaran yang bertujuan agar siswa dalam memahami materi dan penyelesaian masalah yang diberikan, ilustrasi dialog atau "ayo mengamati" yang berisikan dialog atau permasalahan lain yang dapat diamati oleh siswa agar mereka lebih memahami materi, dan rangkuman yang berisikan rangkuman materi dan contoh pada masing-masing subbab yang ada. Dalam bahan ajar interaktif ini, selain berisikan materi juga berisikan video pembelajaran (Gambar 3) dan media pembelajaran interaktif (Gambar 4). Dengan adanya video pembelajaran yang sudah berisikan video bahasa isyarat, siswa tunarungu diharapkan akan menjadi lebih mudah dalam memahami materi yang dibahas. Selain itu, dengan adanya media pembelajaran interaktif ini, siswa diharapkan dapat bereksplorasi dengan materi yang dibahas. Setelah halaman materi, halaman berikutnya adalah halaman latihan soal. Halaman latihan soal ini berisikan soal-soal latihan yang dapat digunakan untuk mengukur kemampuan pemahaman siswa mengenai materi yang telah mereka pelajari dari bahan interaktif pada masing-masing subbab materi yang disediakan (lihat Gambar 5). Setelah halaman materi selesai, halaman selanjutnya adalah halaman daftar

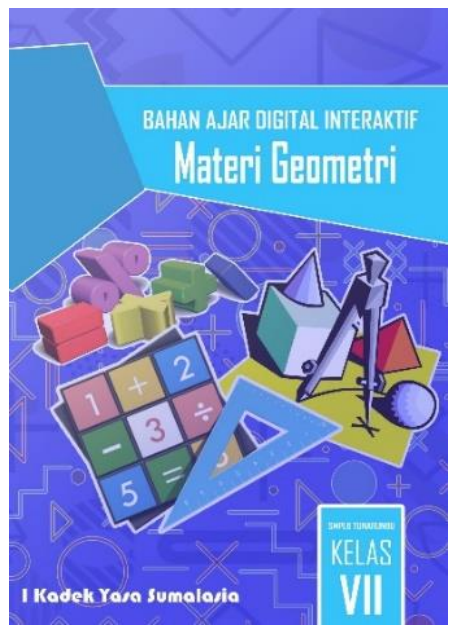

Gambar 1. Halaman sampul pustaka yang berisikan daftar pustaka dari bahan ajar interaktif materi geometri ini dan halaman profil pengembang yang memuat profil pengembang dari bahan ajar interaktif ini.
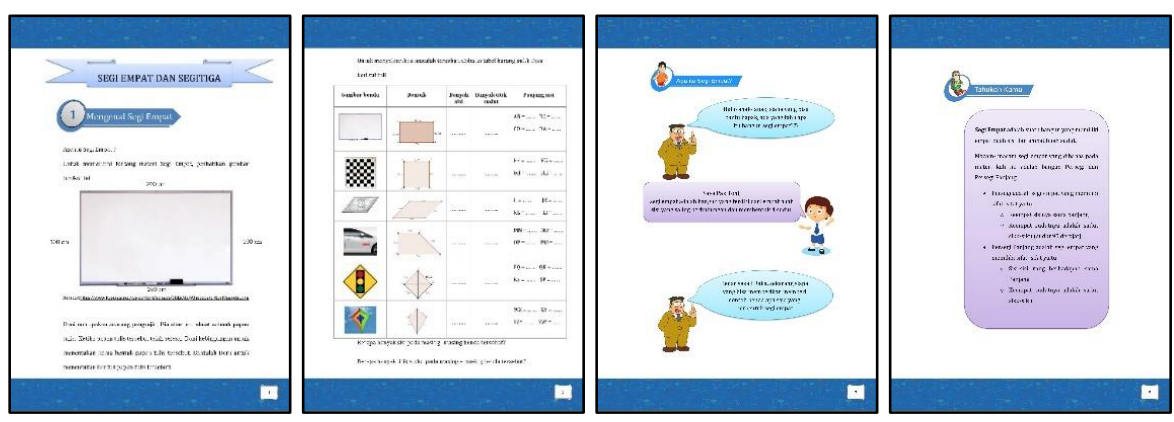

Gambar 2. Contoh tampilan halaman materi bahan ajar interaktif 
PYTHAGORAS: Jurnal Pendidikan Matematika, 15 (1), 2020 - 43

I Kadek Yasa Sumalasia, I Made Suarsana, I Wayan Puja Astawa

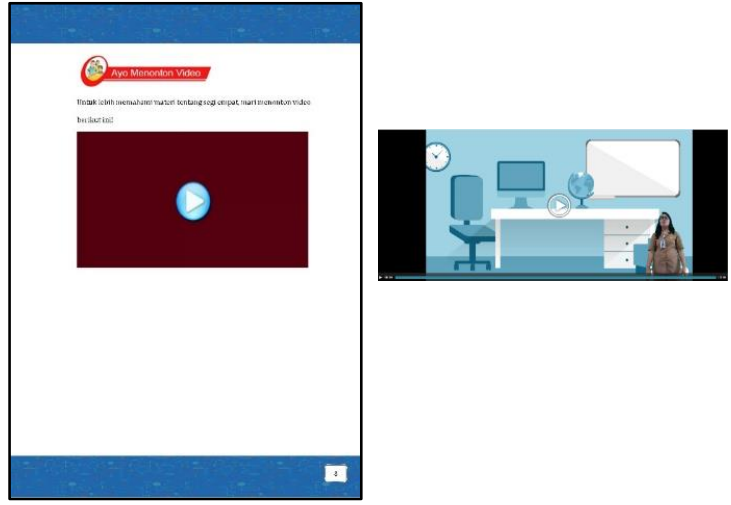

Gambar 3. Contoh halaman video pembelajaran
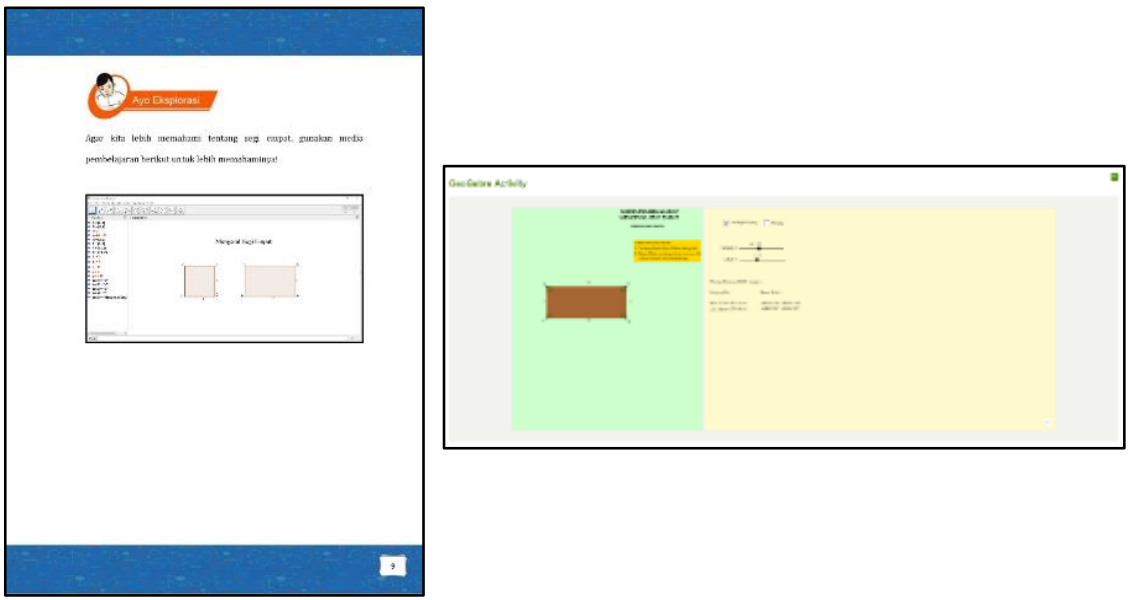

Gambar 4. Contoh halaman media pembelajaran
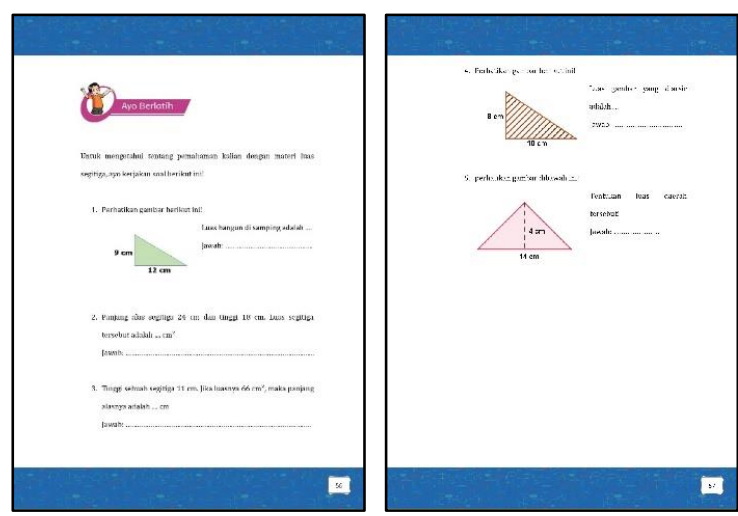

Gambar 5. Contoh halaman latihan soal

Produk akhir (prototipe akhir) bahan ajar interaktif materi geometri yang dihasilkan dalam penelitian ini layak digunakan dalam pembelajaran di kelas apabila bahan ajar tersebut memenuhi tiga kriteria, yaitu valid, praktis, dan efektif. Hasil validasi bahan ajar interaktif dilakukan ahli materi, ahli bahasa, ahli penyajian, dan ahli kegrafikan menunjukkan bahwa bahan ajar interaktif yang dihasilkan termasuk ke dalam kriteria valid dengan rata-rata skor kevalidan sebesar 2,92 (lihat Tabel 5). Ini berarti, bahan ajar yang dihasilkan telah memenuhi kriteria kevalidan yang telah ditetapkan.

Tabel 5. Kevalidan bahan ajar interaktif yang dikembangkan

\begin{tabular}{ccccccc}
\hline \multicolumn{3}{c}{ Rata-rata skor validasi tiap aspek } & Jumlah & Rata-rata & $\begin{array}{c}\text { Kriteria } \\
\text { kevalidan }\end{array}$ \\
\cline { 1 - 3 } Materi & Kebahasaan & Penyajian & Kegrafikan & & 2,92 & Valid \\
\hline 3,00 (valid) & 2,75 (valid) & 3,00 (valid) & 2,94 (valid) & 11,69 & 2 \\
\hline
\end{tabular}


Adapun kepraktisan dari bahan ajar interaktif yang dihasilkan dilihat dari skor angket respons guru dan angket respons siswa terhadap bahan ajar tersebut. Hasil analisis terhadap data kepraktisan bahan ajar dari angket respons guru menunjukkan bahwa bahan ajar tersebut praktis, di mana rata-rata skor kepraktisan yang diperoleh adalah sebesar 4,5 dan ini berada dalam kriteria kepraktisan sangat tinggi. Data dari angket respons siswa juga menunjukkan bahwa bahan ajar yang dihasilkan berada dalam kriteria kepraktisan tinggi dengan rata-rata skor kepraktisan mencapai 3,84. Adapun penilaian terhadap keefektifan dari bahan ajar yang dihasilkan diperoleh melalui data tes hasil belajar siswa. Hasil dari tes hasil belajar siswa dirangkum dalam Tabel 6. Berdasarkan Tabel 6, persentase ketuntasan belajar klasikal telah melebihi batas minimum persentase ketuntasan belajar klasikal yang ditetapkan (85\%), Ini berarti, bahan ajar yang dihasilkan dalam penelitian ini sudah memenuhi kriteria efektif. Dengan kata lain, bahan ajar interaktif tersebut efektif dalam memfasilitasi siswa tunarungu dalam mempelajari materi segitiga dan segiempat, sehingga 90\% dari mereka dapat mencapai hasil belajar melebihi batas minimum yang telah ditetapkan.

Tabel 6. Rangkuman hasil tes hasil belajar siswa

\begin{tabular}{ll}
\hline Aspek penilaian & Hasil \\
\hline Rata-rata & 84,5 \\
Skor tertinggi & 95 \\
Skor terendah & 75 \\
Jumlah siswa tuntas & 9 \\
Jumlah siswa tidak tuntas & 1 \\
Persentase ketuntasan belajar klasikal & $90 \%$ \\
\hline
\end{tabular}

\section{PEMBAHASAN}

Dari penelitian pengembangan yang telah dilakukan ini, dihasilkanlah bahan ajar interaktif multi representasi pada materi geometri untuk siswa kelas VII SMPLB Tunarungu. Kualitas dari bahan ajar yang dihasilkan ini ditentukan berdasarkan kelayakan bahan ajar ditinjau dari tiga kriteria, yaitu kevalidan, kepraktisan, dan keefektifan. Berdasarkan penilaian oleh validator terhadap kevalidan bahan ajar dari aspek validitas materi, kebahasaan, penyajian, dan kegrafikan diperoleh hasil bahwa bahan ajar tersebut berada pada kriteria valid untuk keempat aspek validitas yang ada. Begitu pun untuk kriteria kepraktisan dan keefektifan, bahan ajar yang dihasilkan sudah memenuhi kedua kriteria tersebut. Dengan demikian, dapat dikatakan bahwa bahan ajar interaktif multi representasi yang dihasilkan melalui penelitian pengembangan ini sudah layak untuk digunakan oleh siswa kelas VII SMPLB Tunarungu di dalam proses pembelajaran matematika pada materi geometri.

Seperti yang telah disebutkan sebelumnya, bahan ajar yang dihasilkan dalam penelitian ini memenuhi kriteria valid pada aspek validitas materi. Hal ini dapat tercapai, salah satunya, karena materi yang disajikan dalam bahan ajar telah disesuaikan dengan kompetensi dasar materi geometri untuk siswa kelas VII SMPLB Tunarungu. Lebih lanjut, dari hasil validasi ahli materi diperoleh bahwa materi pembelajaran yang disajikan dalam bahan yang dikembangkan sudah tersusun secara sistematis, alur logis, dan jelas. Selain itu, latihan soal yang termuat dalam bahan ajar sudah sesuai dengan isi pembelajaran dalam bahan ajar tersebut. Adapun hasil penilaian dari ahli kebahasaan menyatakan bahwa bahan ajar interaktif multi representasi materi geometri berada pada kriteria valid. Hasil ini dapat dicapai karena kalimat atau bahasa yang digunakan dalam bahan ajar tersebut dibuat sesederhana mungkin agar dapat lebih mudah dipahami oleh siswa. Bahan ajar ini, bagaimanapun juga, dilengkapi dengan video bahasa isyarat yang dapat memudahkan siswa dalam mengartikan informasi dalam bentuk teks dan memahami materi pembelajaran. Hal ini sejalan dengan tujuan dari penambahan video pembelajaran dengan bahasa isyarat itu sendiri, yaitu untuk mendukung siswa untuk lebih mudah memahami materi pembelajaran yang sedang mereka pelajari (Suarcita et al., 2020). Selain dilengkapi dengan video pembelajaran, bahan ajar yang dikembangkan juga menyajikan materi pembelajaran dalam bentuk gambar dan animasi. Ini dilakukan karena siswa tunarungu lebih banyak menerima informasi secara visual atau dengan kata lain, menurut Chang (Chen, 2014), siswa tunarungu memiliki ketergantungan yang sangat tinggi pada penerimaan informasi secara visual. Berdasarkan penilaian oleh ahli penyajian dan ahli kegrafikan, diperoleh hasil bahwa bahan ajar interaktif yang dikembangkan mencapai kriteria valid dalam aspek penyajian dan kegrafikan tersebut. Dalam bahan ajar ini, materi pembelajaran dikemas dalam bentuk gambar, video, dan media lainnya sehingga siswa menjadi tertarik untuk membaca, memahami, dan mempelajari materi tersebut. Selain itu, siswa juga dapat mencoba bereksplorasi dengan menggunakan media 
interaktif yang disediakan dalam bahan ajar tersebut. Dengan demikian, dapat dikatakan bahwa bahan ajar interaktif yang dikembangkan dapat mengakomodasi keterbatasan yang dihadapi oleh siswa tunarungu dalam pembelajaran, khususnya pembelajaran geometri.

Bahan ajar interaktif multi representasi yang dikembangkan dalam penelitian ini, berdasarkan hasil tes hasil belajar siswa, mampu memfasilitasi siswa tunarungu dalam memahami materi geometri terkait bangun datar segitiga dan segiempat, sehingga sembilan dari sepuluh siswa tunarungu yang menjadi subjek uji coba penelitian ini mampu mencapai nilai tidak kurang dari kriteria ketuntasan minimum. Hasil ini dimungkinkan dapat terjadi karena manfaat dari penggunaan pendekatan multi representasi dalam bahan ajar tersebut. Menurut Treagust (2008), manfaat dari penggunaan multi representasi dalam proses pembelajaran adalah pelengkap dalam mendukung proses kognitif siswa, dapat mendukung siswa dalam mengembangkan pemahaman yang lebih baik terhadap konsep materi yang sedang mereka pelajari, dan memfasilitasi siswa untuk memperoleh pemahaman yang lebih mendalam terhadap konsep yang dapat mengembangkan kemampuan abstraksi, generalisasi, dan membuat koneksi antara berbagai representasi. Pernyataan yang dikemukakan oleh Treagust (2008) tersebut sejalan dengan pernyataan yang dikemukakan oleh Budarsini et al. (2018) bahwa pendekatan multi representasi yang diterapkan dalam lembar kerja siswa dapat menjadikan siswa lebih aktif dalam proses pembelajaran matematika, lebih memahami konsep atau materi yang sedang dipelajarinya, dan tentunya menjadikan pembelajaran lebih bermakna.

\section{SIMPULAN}

Berdasarkan hasil analisis data dan pembahasan yang telah diuraikan, dapat ditarik beberapa kesimpulan. Pertama, bahan ajar yang dihasilkan adalah bahan ajar interaktif multi representasi materi geometri kelas VII SMPLB Tunarungu. Bahan ajar interaktif materi geometri memuat halaman materi pembelajaran, halaman video pembelajaran, halaman media pembelajaran, halaman latihan soal materi geometri, halaman daftar pustaka, dan halaman profil pengembang. Kedua, hasil validasi menunjukkan bahwa bahan ajar yang dikembangkan valid ditinjau dari aspek materi, kebahasaan, penyajian, dan kegrafikan. Hasil penilaian kepraktisan oleh guru dan siswa menunjukkan bahwa bahan ajar yang dikembangkan praktis. Selain itu, bahan ajar interaktif yang dikembangkan juga efektif, di mana $90 \%$ siswa hasil belajarnya mencapai kriteria ketuntasan minimum setelah menggunakan bahan ajar tersebut. Berdasarkan hasil uji coba tersebut, telah diperoleh bahan ajar interaktif dengan pendekatan multi representasi materi geometri kelas VII SMPLB Tunarungu yang layak untuk digunakan. Berdasarkan simpulan tersebut, peneliti menyarankan agar guru SMPLB dapat menggunakan bahan ajar interaktif tersebut sebagai salah satu alternatif untuk meningkatkan kualitas pembelajaran matematika untuk siswa tunarungu. Selain itu, peneliti juga menyarankan agar peneliti lainnya juga dapat mengembangkan bahan ajar serupa pada materi maupun jenjang pendidikan lainnya.

\section{DAFTAR PUSTAKA}

Akpinar, Y. (2008). Validation of a learning object review instrument: Relationship between ratings of learning objects and actual learning outcomes. Interdisciplinary Journal of E-Learning and Learning Objects, 4(1), 291302. http://ijklo.org/Volume4/IJELLOv4p291-302Akpinar.pdf

Astuti, D., \& Trisnawati, T. (2013). Pengembangan bahan ajar matematika untuk SMPLB/B kelas IX berdasarkan Standar Isi. Prosiding Seminar Nasional Matematika dan Pendidikan Matematika FMIPA UNY (pp. 211-218). http://eprints.uny.ac.id/10750/1/P - 27.pdf

Budarsini, K. P., Suarsana, I. M., \& Suparta, I. N. (2018). Model diskursus multi representasi dan kemampuan pemahaman konsep matematika siswa sekolah menegah pertama. Pythagoras: Jurnal Pendidikan Matematika, 13(2), 110-118. https://doi.org/10.21831/pg.v13i2.20047

Chen, Y.-T. (2014). A study to explore the effects of self-regulated learning environment for hearing-impaired students. Journal of Computer Assisted Learning, 30(2), 97-109. https://doi.org/10.1111/jcal.12023

Duta, N., Panisoara, G., \& Panisoara, I.-O. (2015). The effective communication in teaching: Diagnostic study regarding the academic learning motivation to students. Procedia-Social and Behavioral Sciences, 186(1), 1007-1012. https://doi.org/10.1016/j.sbspro.2015.04.064 
Gafoor, K. A., \& Kurukkan, A. (2015). Learner and teacher perception on difficulties in learning and teaching mathematics: Some implications. National Conference on Mathematics Teaching - Approaches and Challenges, pp. 232-243. https://files.eric.ed.gov/fulltext/ED568368.pdf

Gazali, R. Y. (2016). Pengembangan bahan ajar matematika untuk siswa SMP berdasarkan teori belajar Ausubel. Pythagoras: Jurnal Pendidikan Matematika, 11(2), 182-192. https://doi.org/10.21831/pg.v11i2.10644

Hernawati, T. (2007). Pengembangan kemampuan berbahasa dan berbicara anak tunarungu. Jurnal Asesmen Dan Intervensi Anak Berkebutuhan Khusus, 7(1), 101-110.

http://file.upi.edu/Direktori/FIP/JUR._PEND._LUAR_BIASA/196302081987032-TATI_HERNAWATI/jurnal.pdf

Hidayat, L., Gunarhadi, G., \& Hidayatulloh, F. (2017). Multimedia based learning materials for deaf students. European Journal of Special Education Research, 2(3), 77-87. https://doi.org/10.5281/zenodo.376744

Hidayati, H. (2012). Strategi guru dalam membelajarkan matematika pada sub pokok bahasan sifat-sifat bangun datar kepada anak tunarungu (Studi kasus pada siswa kelas V SLB-B YRTRW Surakarta). Journal of Mathematics and Mathematics Education, 2(1), 81-92. https://doi.org/10.20961/jmme.v2i1.9952

Kemendikbud. (2014). Peraturan Menteri Pendidikan dan Kebudayaan Republik Indonesia Nomor 157 Tahun 2014 tentang kurikulum pendidikan khusus. http://simpuh.kemenag.go.id/regulasi/permendikbud_157_14.pdf

Kemendiknas. (2008). Peraturan Menteri Pendidikan Nasional Republik Indonesia Nomor 33 Tahun 2008 tentang Standar Sarana dan Prasarana untuk Sekolah Dasar Luar Biasa (SDLB), Sekolah Menengah Luar Biasa (SMPLB), dan Sekolah Menengah Atas Luar Biasa (SMALB). https://bsnp-indonesia.org/id/wpcontent/uploads/2009/06/Nomor-33-Tahun-2008.pdf

Krasavina, Y. V., Serebryakova, Y. V., Ponomarenko, E. P., \& Zhuykova, O. V. (2019). Research-based teaching of hearing-impaired students. Proceedings of International Forum on Teacher Education, 1387-1394. https://doi.org/10.3897/ap.1.e1316

Liando, J., \& Dapa, A. (2007). Pendidikan anak berkebutuhan khusus dalam perspektif sistem sosial. Direktorat Ketenagaan, Direktorat Jenderal Pendidikan Tinggi, Departemen Pendidikan Nasional.

Muhidin, S. A., \& Abdurahman, M. (2007). Analisis korelasi, regresi, dan jalur dalam penelitian. Pustaka Setia.

Novitasari, D. (2016). Pengaruh penggunaan multimedia interaktif terhadap kemampuan pemahaman konsep matematis siswa. Fibonacci:Jurnal Pendidikan Matematika dan Matematika, 2(2), 8-18. https://doi.org/10.24853/fbc.2.2.8-18

Presiden Republik Indonesia. (2003). Undang-Undang Republik Indonesia Nomor 20 Tahun 2003 tentang Sistem Pendidikan Nasional. http://ldikti3.ristekdikti.go.id/html/wp-content/uploads/2011/04/sisdiknas.pdf

Rawat, D. (2016). Importance of communication in teaching learning process. Scholarly Research Journal for Interdisciplinary Studies, 4(26), 3058-3063.

http://www.srjis.com/pages/pdfFiles/148360449445.\%20PAPER_SONALI\%20FINAL\%20(\%20elixr).pdf

Sholihah, W., Susanto, S., \& Sugiarti, T. (2015). Pengembangan bahan ajar (buku siswa) matematika untuk siswa tunarungu berdasarkan standar isi dan karakteristik siswa tunarungu pada sub pokok bahasan menentukan hubungan dua garis, besar sudut, dan jenis sudut kelas VII SMPLB/B Taman Pendidikan dan Asuhan. Pancaran, 4(1), 219-228. https://jurnal.unej.ac.id/index.php/pancaran/article/download/1344/1101/

Siregar, N. R. (2017). Persepsi siswa pada pelajaran matematika: studi pendahuluan pada siswa yang menyenangi game. Prosiding Temu Ilmiah X Ikatan Psikologi Perkembangan Indonesia (pp. 224-232). http://jurnal.unissula.ac.id/index.php/ippi/article/view/2193

Suarcita, G. P., Astawa, I. W. P., \& Suarsana, I. M. (2020). Pengembangan bahan ajar digital interaktif dengan pendekatan multi representasi pada materi bilangan bulat untuk siswa SMPLB tunarungu. Akademika: Jurnal Teknologi Pendidikan, 9(1), 69-84. https://doi.org/10.34005/akademika.v9i01.731

Suarsana, I. M., Mahayukti, G. A., Sudarma, I. K., \& Pujawan, A. A. G. S. (2019). The effect of interactive mathematics learning media toward mathematical conceptual understanding on probability of hearing-impaired students. Journal of Physics: Conference Series, 1165(1), 1-8. https://doi.org/10.1088/1742-6596/1165/1/012021 
PYTHAGORAS: Jurnal Pendidikan Matematika, 15 (1), 2020 - 47

I Kadek Yasa Sumalasia, I Made Suarsana, I Wayan Puja Astawa

Suarsana, I. M., Mahayukti, G. A., Sudarma, I. K., \& Yoga, I. N. B. A. (2018). Development of interactive mathematics learning media on statistics topic for hearing-impaired student. International Research Journal of Engineering, IT \& Scientific Research, 4(6), 55-66. https://doi.org/10.21744/irjeis.v4n6.377

Treagust, D. F. (2008). The role of multiple representations in learning science. In Y.-J. Lee \& A.-T. Tan (Eds.), Science education at the nexus of theory and practice (pp. 7-23). Sense. https://doi.org/10.1163/9789087904227_003

Waldrip, B., Prain, V., \& Carolan, J. (2006). Learning junior secondary science through multi-modal representations. Electronic Journal of Science Education, 11(1), 87-107. https://ejse.southwestern.edu/article/view/7752

Yeni, E. M. (2015). Kesulitan belajar matematika di sekolah dasar. Jurnal Pendidikan Dasar (Jupendas), 2(2), 1-10. http://www.jfkip.umuslim.ac.id/index.php/jupendas/article/view/231 